\title{
Influence of material characteristics stress-strain on the results of FEM joint connection of cold-formed sections
}

\author{
Mariusz Kosiń ${ }^{1}$
}

\begin{abstract}
:
Performing a numerical analysis in the nonlinear range requires entering appropriate input data for the material. For this purpose, the actual stress-strain characteristic is used for the finite element calculation. In order to establish the actual stress-strain curve, a simple tensile test of a steel specimen was performed. The stress-strain curve obtained from the numerical analysis was compared with the tensile test result. Additionally, the work compares the use of three material models for the screw connection of cold-bent elements on the basis of the numerical analysis performed. One of the models used for the calculations was based on the characteristics of a bilinear material with gain. The remaining ones were defined on the basis of the tensile test curve and the real curve obtained from transformations.
\end{abstract}

\section{KEYWORDS:}

real curve; engineering curve; FEM; cold-bent profiles

\section{Introduction}

Complex numerical simulations require the introduction of appropriate input data for the creation and validation of computer models with experiments. This is particularly true for plastic analysis where different material models are used. The stress-strain characteristics used for a given material are determined on the basis of the course of experiment, e.g. uniaxial tensile testing, and presented by means of a diagram. There are three types of these charts. A machine diagram which is the relationship between the applied force and the displacement recorded directly by the measuring system of the testing machine. The second is the stress-strain diagram, in which, among others, the actual loading force is related to the initial cross-sectional area of the tested element. Finally, another characteristic can be obtained as a result of the stress-strain conversion of the engineering curve by means of logarithmic equations into a real curve.

Simplified material models are used to carry out simple numerical analyzes. Such a model is a bilinear stress-strain curve with or without reinforcement. More precise results are obtained taking into account the actual stress-strain characteristics with its elastic and plastic parts.

In this work, numerical validation was performed with the conducted tensile tests of steel in order to determine the material characteristics. Additionally, the influence of the adopted characteristics on the results of numerical calculations of the screw joint of cold-formed elements was discussed. For comparison with the real curve, a simplified bilinear model with gain was adopted. The analysis was carried out in the Ansys Research 2021 program based on the finite element method.

1 Czestochowa University of Technology, Faculty of Civil Engineering, ul. Akademicka 3, 42-218 Czestochowa, e-mail: mariusz.kosin@pcz.pl, orcid id: 0000-0003-2683-7784 


\section{Defined material models for FEM analysis}

In order to determine the material characteristics, a uniaxial tensile test was carried out on cylindrical samples (Fig. 1). The test was performed on a testing machine up to $100 \mathrm{kN}$.

a)

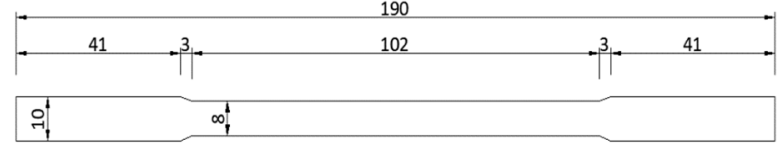

b)

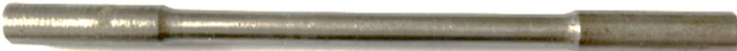

c)

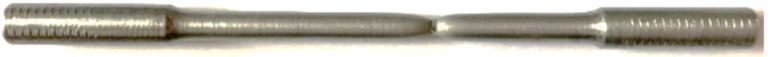

d)

Fig. 1. Geometry of steel specimens used in the uniaxial tensile test: a) dimensions of the test sample in millimeters, b) view of the specimen before testing, c,d) view of the specimens after the test.

Based on the recorded results, the basic parameters describing the characteristics of the tested material were determined: yield stress fy $=350.14 \mathrm{MPa}$, tensile strength $\mathrm{fu}=444.04 \mathrm{MPa}$ and Young's modulus equal to $200 \mathrm{GPa}$.

The result of the tensile test is a force-displacement curve that has been converted into a stress-strain engineering characteristic. The engineering stress $\sigma_{e n g}[\mathrm{MPa}]$ is expressed as the ratio of the loading force $\mathrm{F}[\mathrm{N}]$ to the initial area of the cross-section $\mathrm{A}[\mathrm{mm}]$ of the tensioned bar:

$$
\sigma_{\text {eng }}=\frac{F}{A}
$$

where: $\sigma_{\text {eng }}$ - engineering stress [MPa], $\mathrm{F}$ - loading force $[\mathrm{N}], \mathrm{A}$ - initial cross-sectional area of the sample [mm].

The engineering strain $\varepsilon_{\text {eng }}$ was determined on the basis of:

$$
\varepsilon_{\text {eng }}=\frac{\Delta L}{L}
$$

where: $\varepsilon_{\text {eng }}$ - engineering strain, $\Delta \mathrm{L}$ - change of sample length depending on the loading force $[\mathrm{mm}], \mathrm{L}$ - initial sample length [mm].

The stress value at each point of the stress-strain engineering characteristic is determined in the un-deformed original state of the sample, which makes the use of the engineering curve as a material property in numerical analyzes incorrect [1-3]. Therefore, it is necessary to transform the engineering curve into a real stress-strain curve, in which the deformation state of the sample $\mathrm{L}[\mathrm{mm}]$ is related to the successive extensions $\Delta \mathrm{L}[\mathrm{mm}]$. The implementation of the stress-strain engineering characteristic without conversion to the real curve may cause a calculation error not only at the end point of the strength curve, but in the entire plastic area. We convert the engineering curve to the real curve using logarithmic equations (4) and (5). Assuming that the volume $V$ of the material remains unchanged in the uniaxial tensile test, we obtain the following relationships between the actual stresses and strains and the engineering stresses and strains:

$$
\begin{gathered}
V=\text { const } \\
\sigma_{\text {true }}=\frac{F}{A}=\frac{F L_{o}}{A L}=\sigma_{\text {eng }}=\sigma_{\text {eng }}\left(1+\varepsilon_{\text {eng }}\right)
\end{gathered}
$$




$$
\varepsilon_{\text {true }}=\int_{L}^{L_{o}} \frac{d L_{o}}{L_{o}}=\ln \left(1+\varepsilon_{\text {eng }}\right)
$$

where: $\mathrm{V}$ - bar volume during deformation $\left[\mathrm{mm}^{3}\right]$, $\sigma_{\text {true }}$ - true stress $[\mathrm{MPa}], \varepsilon_{\text {true }}-$ true strain, $\sigma_{\text {eng }}$ - engineering stress [MPa], $\varepsilon_{\text {eng }}-$ engineering strain.

Expressions (4) and (5) lose their validity when the transverse section (the so-called neck), where the costs of permanent deformation with better and better transport, are no longer valid. In Figure 2 it can be seen that the stress-actual strain curve is greater than the engineering strain.

Engineering stress on the load carried by the specimen divided by the variable original surface. Due to the equalization of the deformation along the tested sample, the actual stress can be calculated as the division of the axial and the planar transverse version of the transverse test sample (4).

The engineering strain, defined as the relative elongation of the entire specimen, is the strain averaged over the entire specimen length. The actual deformation in the throat area of the sample is much greater. The actual deformation is characterized by the division of the deformation increment and the actual length (5). In the area of destruction, the sample significantly narrows (the so-called "neck" is formed) and the real area is much smaller, and thus the actual stress is much greater than the engineering stress.

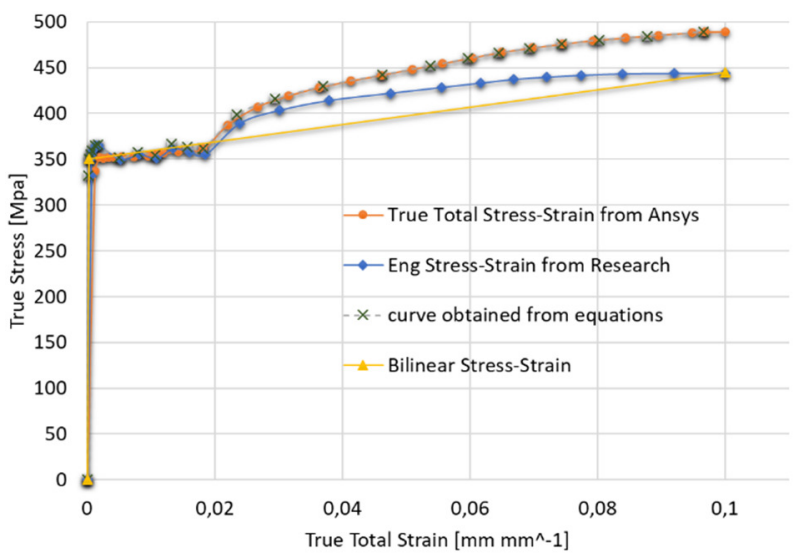

Fig. 2. Material models adopted for numerical analysis

The material characteristics used for the analysis are shown in Figure 2. Apart from the engineering curve and the real curve, the bilinear characteristics of the material were also used for comparative purposes (Fig. 2). The bilinear model of the material was based on the yield stress fy $=350 \mathrm{MPa}$ Young's modulus $\mathrm{E}=200 \mathrm{GPa}$ and the tangential plastic modulus $\mathrm{E} \mathrm{Epl}=1.45 \mathrm{GPa}$.

Figure 2 also shows the results of the real curve obtained from transformations using equations (4) and (5) with the obtained stress-strain curve as a result of simulating the uniaxial tensile test of the sample with the dimensions given in Figure 1a. The performed numerical analysis reflects the nature of the real curve obtained from logarithmic transformations.

\section{Numerical model of the connection of cold-formed elements}

The numerical simulation was performed using Ansys Academic Research 2020R1 software, based on the finite element method. The scope of the numerical analysis assumed the modeling of a thin-walled profile using a shell model of the Shell181 type. The screws, on the other hand, used the Solid187 solid model. The analyzed connection consisted of a C 140 channel with stiffener and a U143 channel without reinforcements $1.5 \mathrm{~mm}$ thick. The elements were connected with screws with a diameter of $4.8 \mathrm{~mm}$. The finite element mesh was generated in the Multizone mode (Fig. 3b), based on cubic elements, which guarantees the formation of a smaller number of nodes 
and elements and greater accuracy of results compared to tetrahedral meshes $[4,5]$. The view of the numerical model with the boundary conditions is shown in Figure 3. For the purposes of the calculations, the analyzed connection was loaded with a vertical displacement of $6 \mathrm{~mm}$, causing stretching of the C140 section (Fig. 3a). This allowed for the analysis of the critical state in the plastic area. As a support, the lower part of the U145 profile element was restrained (Fig. 3a).

a)

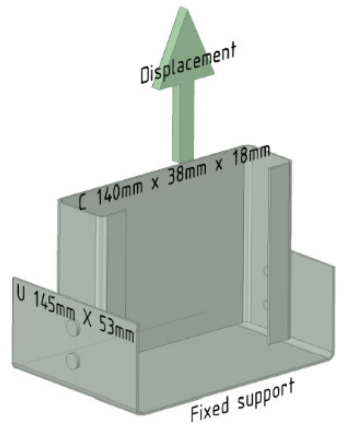

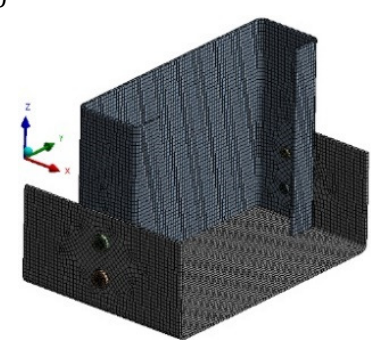

Fig. 3. Model of the screw connection of cold-formed sections: a) boundary conditions of the analyzed fragment, b) mesh view

Two types of contact were adopted for modeling the contacts between the elements. Bonded contact, which means that the pair of contacts cannot separate and move, and Frictional contact that allows the contacts to separate and shift to one another. Similar types of contacts was discussed in [4-6]. A bonded contact was used to connect the cold-rolled elements with the screw. On the other hand, at the joint of the profiles, a frictional contact with a friction coefficient of 0.8 was assumed, which corresponds to the steel-steel friction coefficient $[4,7]$.

\section{Numerical analysis results}

Figure 4 shows the operating curves of the bolted connection of cold-formed elements for the assumed material characteristics. Based on the analysis, the stresses reduced for the bilinear curve are approx. $15 \%$ greater than that obtained from the real curve. On the other hand, the simulation of the connection of cold-formed elements, taking into account the engineering curve, will show reduced stresses by $8 \%$ in relation to the real characteristic. The approach with the bilinear model leads to an overestimation of the load capacity of the structure and, as a result, may result in the failure of the structure due to overloading.

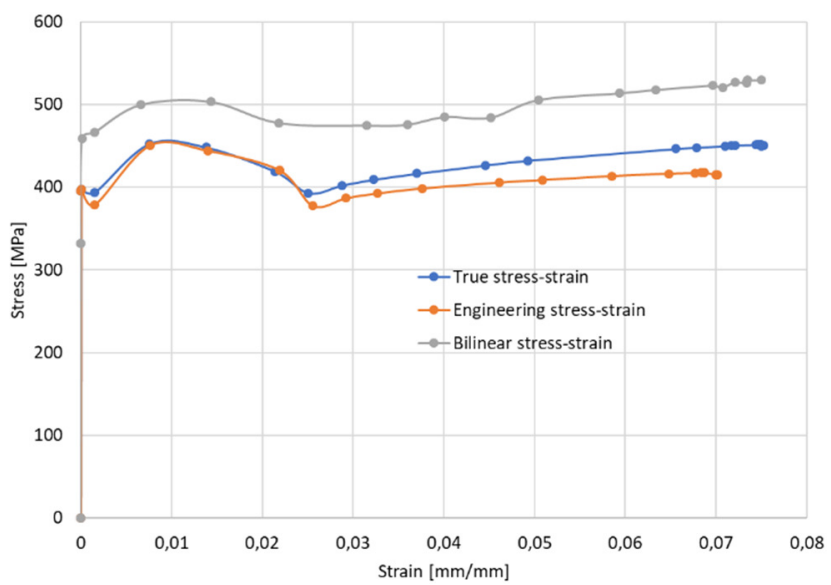

Fig. 4. Stress-strain curves obtained from the numerical analysis of the screw connection of cold-formed elements 
The simulation reflecting the nature of the real curve was created in Ansys on the basis of a multiline model. Figure 4 shows a change in the material model scheme, which significantly lowered the load capacity of the analyzed connection. The presented stress-strain curves, apart from differences in load capacity, reflect the similar nature of the work of all three material models.

\section{Conclusions}

The main objective of the research was to present the use of the real stress-strain curve as a correct material property to perform a numerical analysis in the nonlinear range. The presented simulation shows that the adopted material model has an impact on the results obtained in the analysis of elasto-plastic states of nonlinear stability using the finite element method. A generalized approach found in the literature, based on a bilinear model, may lead to an erroneous estimation of the bearing capacity, in this case, of a screw connection. Also, the comparison of the operating curves of the analyzed screw connection of cold-formed elements with the use of the engineering curve leads to erroneous results, which is confirmed by the above studies.

\section{References}

[1] Gannon L., Mesh Dependence of True Stress-Strain Curves in Finite Element Analysis of Steel Structures, DRDC Atlantic TM 2001-283; Defence R\&D Canada - Atlantic, 2011.

[2] Ehlers S., Strain and stress relation until fracture for finite element simulations of a thin circular plate, Thin-Walled Structures 2010, 48.

[3] Petrik A., Aroch R., Usage of true stress-strain curve for FE simulation and the influencing parameters, IOP Conf. Materials Science and Engineering 2019, 566.

[4] Kosiń M., Major M., Major I., Kalinowski J., Model Tests of Bending and Torsional Deformations of Thin-Walled Profiles Stiffened with Elements Made in 3D Printing Technology, Case Studies in Construction Materials, Elsevier, 2020

[5] Major M., Major I., Kosiń M., Numerical static analysis of the curtain wall with light steel structure, Transactions of the VSB - Technical University of Ostrava. Civil Engineering Series, 2017.

[6] Major M., Kosiń M., Kalinowski J., Analysis of a selected node of a truss made of cold-rolled sections based on the finite element method, Transactions of the VSB - Technical University of Ostrava. Civil Engineering Series, Ostrava, 2018

[7] Kosiń M., Numerical analysis of the stability of a two-story building made using a light steel skeleton frame, Zeszyty Naukowe Politechniki Częstochowskiej 2019, seria Budownictwo 25, 92-98.

\section{Wpływ charakterystyki materiałowej naprężenie-odkształcenie na otrzymane wyniki MES połączenia śrubowego kształtowników zimnogiętych}

\section{STRESZCZENIE:}

Wykonanie analizy numerycznej w zakresie nieliniowym wymaga wprowadzenia odpowiednich danych wejściowych materiału. W tym celu do obliczeń metodą elementów skończonych wykorzystuje się rzeczywistą charakterystykę naprężenie-odkształcenie. W celu ustalenia rzeczywistej krzywej naprężenie-odkształcenie przeprowadzono prostą próbę rozciągania stalowej próbki. Uzyskaną z analizy numerycznej krzywą naprę żenie i odkształcenie porównano $\mathrm{z}$ wynikiem próby rozciagania. Dodatkowo w pracy porównano na podstawie przeprowadzonej analizy numerycznej wykorzystanie trzech modeli materiałowych dla połączenia śrubowego elementów zimnogiętych. Jeden z modeli użytych do obliczeń opierał się na charakterystyce materiału bilinearnego z wzmocnieniem. Natomiast pozostałe zdefiniowano na podstawie krzywej z próby rozciągania i uzyskaną z przekształceń krzywą rzeczywistą.

SŁOWA KLUCZOWE:

krzywa rzeczywista; krzywa inżynierska; MES; profile zimnogięte 